At our first meeting in the new year, held Jan. 20, Mr. W. J. McDonald gave us an interesting report on efforts made the past two summers to locate sites of historic forts along the waters of the Assiniboine river, north-east of Yorkton.

Mr. McDonald said that further maps and descriptions of the location of Fort Alexandria, have been received from the Department of Archives at Ottawa and offorts to find the site will again be made this coming summer. Fort Alexandria, established by Daniel Harmon, was one of the earliest forts built in this part of Saskatchewan. Mr. McDonald said the possible site of the fort has now been narrowed down to a three mile section of the river.

Other fort sites being sought are: Fort Hibernia a North West Company fort built in 1803; Grant's House, known also as Aspin House, built by Cuthbert Grant in 1793; Carlton House, sometimes known as Fort Assiniboine, the first Hudson Bay Company fort on the Assiniboine river built in 1790; Marlboro House opposite Carlton House and Belleau's fort, a free traders establishment near Fort Pelly.

The society has obtained a picture of Fort Pelly and a copy will be placed in the city hall files. Mr. Fred Lanzstaff described the Fort Pelly buildings and their furnishins as he saw them during visits to the Fort about 1895. Films nertaining to explorations were shown by Mr. Paul Wellgan.

\title{
CONSERVATION
}

Effective conservation of our wild life depends upon the attitude of our youth, and so we should do all in our power to encourage our young men and women to think alon these lines.

The following was written by a studen of the Provincial Correspondence school in answer to a question asked on an assignment dealing with conservation problems. We tend our congratulations to Miss Edith Allenbrand of Handel, Saskatchewan.

"Before the red lily (we call it Tiser Iily) became the emblem of our province - before, indeed, I was old enough to know what the word means, my parents taught my brothers and sisters and me high ideals concerning our beautiful flowers. We learned as soon as we learned to walk to turn our footsteps toward nature and we wandered alone, by twos and threes, or the whole family together across the railway track and down the ravine to the Lake.

Down along the Four Mile Lake, as along other small lakes where there is seldom water in July, the Tiger Lily grew brilliant and beautiful. We prized it highly, amons all our flowers, perhaps the most highly, probably because five of us are redheads and our vanity nourished on flattering comparisons.

At any rate, we loved the Western Red Lily and it is a love that will never, never die.

According to their way of teachins, Mom and Dad did the things when we were small that they expected us to do when we grew up. When the lilies grew thick we picked some for our table. When they were only scattered among the grasses we left them there "for next year." It was not a conscious conservation. It was the instinct of preservation born in men who love the soil. 

With an old Bennett wagon and a team of mules that were colts we didn't get very far from home. Our recreation depended on nature. The thirties were hard years for the red lilies. They became our emblem unconsciously. We dug up a couple of roots for our flower bed, but they didn't survive the summer heat. We found them only near the lake, and they slowly disappeared from there.

Now we are older and greater responsibilities take larger shares of our time. But though visits to nature are less frequent they are still a part of our Iives. Last year we wandered along the lake in search of berries as we have always done. And last year, after years of absence, there were lilies. It was not premedited, a scientific thought or action. It was a rebirth of our childhood. We gazed on them gloriously alive above the sunscorched grasses. Spontaneously we knelt to touch the velvet dresses and rose to leave them glowing in the sunset."

Miss Allenbrand's essay was published in the September, 1947, issue of the Country Guide.

\section{BIRD NOTES}

Blue Jay: With Blue Jays being reported as more common than usual in the east central part of Saskatchewan all during the past summer it is most interesting to note that members of the Yorkton N.H.S. noted 7 in their Christmas count at Yorkton.

Willow Ptarmigan: The lone individual noted by $C$. Stuart Francis at Torch River at Christmas is only the second report of this northern species received by the "Blue Jay" in the past six years. During the $1930^{\prime} \mathrm{s}$, Ptarmigan were regularly seen each winter in the more northern settled regions.

During $1947 \mathrm{Mr}$. Arthar Ward, Burnham, reports banding 1.42 individuals of 24 species, including the following species: Orange-crowned Warbler, I; White-winged Crossbill, 3; Pine Siskin, 5; Least Sandpiper, 1. Three Brown Thrashers banded by Mr. Ward returned to the traps a total of thirteen times during the summer. Mr. Ward lives on the bare prairie and a rather remarkable number of birds are attracted to the shelter belt and lawns around his home.

Mr. Chas. F. Holmes, R. R. 3, Salmon Arm, B. C., writes: "I have changed my address after residing in S.W. Saskatchewan for 39 years. I was sorry to leave for many reasons and particularly sorry to no longer be able to keep tab on the wild life there." Mr. Holmes will be well rerribed, while residing at Dolilard, Sask., for his fine renresentative collection of birds, $\mathrm{Mr}$. Holmes sends us a Christmas count taken during a wilk of some 4 miles south of Shuswap Lake, B. C. Pheasant, I; Flicker 4; American Crow, 300 (est.) Chickadee, 15; Brown Creeper, 3; Bohemian Waxwing, 25; Pine Grosbeak, 16; Magpie, 4 .

\section{THE WINTER OF $1946-47$}

The winter of 1946-47 was such an outstanding one from the point of depth of snow, that for reference, it should be kept in mind. After the New Year the snow piled up in the woods in a manner rarely seen. Drifts were in many cases 12 to 14 feet deep, and all around the smaller bluffs there were snowdrifts six to twelve feet deep; 